\title{
Sensitive detection of BRAF V600E mutation by Amplification Refractory Mutation System (ARMS)-PCR
}

Tiangui Huang ${ }^{*}$, Jian Zhuge ${ }^{\dagger}$ and Wenyong W Zhang ${ }^{*}$

\begin{abstract}
Background: BRAF mutations occur in approximately $8 \%$ of all human cancers and approach $50 \%$ in melanoma and papillary carcinoma of thyroid. These mutations provide potentially valuable diagnostic, prognostic and treatment response prediction markers. A sensitive, specific, low-cost assay to detect these mutations is needed.

Results: To detect BRAF V600E mutation in formalin-fixed, paraffin-embedded (FFPE) tissue, we developed a method using Amplification Refractory Mutation System (ARMS)-PCR. This method was designed to amplify three products in a single reaction tube: a 200 bp common product serving as an amplification control, a 144 bp BRAF V600E specific product, and a $97 \mathrm{bp}$ wild-type (wt) specific product. The sensitivity of this method was determined to be as low as $0.5 \%$ for the BRAF V600E allele in a wild-type background. This method was successfully validated in 72 thyroid tumors. It detected V600E mutation in 22 out of 33 (67\%) of the conventional papillary thyroid carcinoma (PTC), 8 out of 12 (75\%) of the tall-cell variant of PTC, whereas none of the 10 follicular variant of PTC showed BRAF V600E mutation. In addition, none of the 14 follicular adenomas and 3 follicular carcinomas had BRAF V600E mutation. As a comparison method, direct dideoxy sequencing found only 27 out of 30 (90\%) mutations detected by ARMS-PCR method, suggesting that this ARMS-PCR method has higher sensitivity.

Conclusions: Our ARMS-PCR method provides a new tool for rapid detection of BRAF V600E mutation. Our results indicate that ARMS-PCR is more sensitive than automated dideoxy sequencing in detecting low BRAF V600E allele burdens in FFPE tumor specimen. The strategy of this ARMS-PCR design may be adapted for early detection of point mutations of a variety of biomarker genes.
\end{abstract}

\section{Background}

$B R A F$ gene encodes a serine/threonine protein kinase that functions downstream of RAS in the RAS-RAF-MEK-ERK signaling pathway, also known as mitogen activated protein kinase (MAPK) pathway, which is important in regulating cellular responses to extracellular signals including epidermal growth factor (EGF) [1]. Upon activation by receptor binding, RAS proteins recruit RAF to the cellular membrane where RAF is phosphorylated [2]. Activated RAF proteins further phosphorylate MEK1 and MEK2, which then phosphorylate ERK1 and ERK2. Phosphorylated ERK proteins regulate cellular functions through activation of transcription factors including p53, SMAD4,

\footnotetext{
*Correspondence: huangt@wcmc.com; wenyongzhang@gmail.com ${ }^{\dagger}$ Equal contributors

Department of Pathology, Westchester Medical Center and New York Medical College, Valhalla, NY 10595, USA
}

ELK1, c-Myc and c-Fos [2,3]. Activating mutations in RAS and $B R A F$ permit constitutive MAPK pathway activation independent of growth factor stimulation, thereby causing deregulation in cellular growth and survival. BRAF mutations occur in approximately $8 \%$ of all human cancers, with high mutation frequency in malignant melanoma (50-70\%), classic papillary carcinoma of the thyroid (40-70\%), colorectal cancer (CRC, 5-15\%), ovarian cancer and hairy cell leukemia (5-100\%) [4,5]. A T1799A transversion resulting in valine-to-glutamate substitution at codon 600 (V600E) accounts for over $80 \%$ of all BRAF mutations [6,7], and almost all mutations in thyroid tumors [8].

Molecular testing for BRAF mutation can provide valuable diagnostic information, treatment selection, and may help predict prognosis. Like KRAS mutations, CRC patients with activating $B R A F$ mutations do not respond 
to anti-EGFR monoclonal antibody (MoAb) treatment $[9,10]$. Because BRAF mutations occur in $5-15 \%$ of CRC and are usually mutually exclusive with KRAS mutations [11], a substantial number of these CRC patients may benefit from $B R A F$ mutation testing before initiating MoAb treatment [9]. In thyroid, $B R A F$ V600E mutation is restricted to malignant tumors, and is associated with papillary thyroid cancer (PTC), and PTC-derived poorlydifferentiated and anaplastic carcinoma $[7,8]$. Therefore, $B R A F$ mutation testing can be helpful as an adjunct method to improve diagnostic accuracy in difficult cases, such as thyroid FNA samples with indeterminate and atypical cytology [12,13].

There are several methods for BRAF V600E mutation testing, including dideoxy sequencing, colorimetric Mutector assay, allele-specific real-time PCR, pyrosequencing, high resolution melting (HRM) analysis and COLD-PCR [14-17]. These methods vary in their sensitivity, assay complexity and costs. Automated dideoxy sequencing is considered the "gold standard" method for mutation testing. However, it is limited by relatively complex procedure, overall high costs and low analytical sensitivity of detecting approximately $15-20 \%$ mutant allele in a wild-type background [18]. ARMS-PCR is a highly sensitive, specific and low-cost mutation detection method with reported analytical sensitivity ranging from $0.1 \%$ to $2 \%$ for JAK2 V617F mutation detection $[19,20]$. Here we report the development of a highly sensitive and specific ARMS-PCR assay to detect BRAF V600E mutation in formalin-fixed, paraffin-embedded (FFPE) tissue with sensitivity as low as $0.5 \%$. We successfully used this assay to characterize the frequency of $B R A F$ V600E in thyroid tumors.

\section{Methods}

\section{Sample source}

Cell lines HT-29 (heterozygous for BRAF V600E) and K562 (wt BRAF without V600E mutation) were cultured in RPMI1640 supplemented with $10 \%$ fetal calf serum. Anonymized FFPE thyroid tumor tissue blocks were obtained from the Department of Pathology for clinical protocol development.

\section{DNA extraction}

3-5 sections of FFPE tissues (5 micron/section) were deparaffinized by xylene and ethanol treatment, and digested with proteinase $\mathrm{K}$ at $56^{\circ} \mathrm{C}$ overnight. Genomic DNA was extracted using ZR genomic DNA I kit (ZYMO Research Corp., Orange, CA) as recommended. DNA extraction from culture cells was otherwise the same as above except no deparaffinization was performed. DNA was then qualified/quantified with ND-1000 spectrophotometer (NanoDrop Products, Wilmington, DE).

\section{ARMS-PCR and sequencing}

The ARMS-PCR primer sequences were forward (Fo): 5 -CTCTTCATAATGCTTGCTCTGATAG-3'; reverse (Ro): 5'-GCCTCAATTCTTACCATCCAC-3'; forward wild-type identifying (Fiwt): 5'-GTGATTTTGGTCT AGCTACAGT-3' and reverse mutation identifying (Rimut):5' -CCCACTCCATCGAGATTTCT-3'. PCR was performed in a $25 \mu \mathrm{l}$ final volume containing $1 \times$ Buffer, $2 \mathrm{mM} \mathrm{MgCl}$, 1 unit of Hotstar Taq DNA polymerase (Qiagen Science, Valencia, CA), $200 \mu \mathrm{M}$ each dNTP, 400 $\mathrm{nM}$ primer Fo, $200 \mathrm{nM}$ primer Ro and Fiwt, $800 \mathrm{nM}$ primer Rimut and 30 ng genomic DNA template. PCR amplification was carried out by denaturation at $95^{\circ} \mathrm{C}$ for $5 \mathrm{~min}$, followed by 40 cycles of $94^{\circ} \mathrm{C}$ for $20 \mathrm{sec}, 68^{\circ} \mathrm{C}$ for $20 \mathrm{sec}$ and $72^{\circ} \mathrm{C}$ for $20 \mathrm{sec}$ with a final extension at $72^{\circ} \mathrm{C}$ for $5 \mathrm{~min}$. PCR products were analyzed by $2 \%$ agarose gel electrophoresis. Automated dideoxy sequencing was performed by Macrogen USA (Rockville, MD) after PCR amplification using the Fo-Ro primer pair and the ampliocons purification using QIAquick PCR purification kit (Qiagen).

\section{Assay sensitivity study}

HT-29 cell DNA with heterozygous BRAF V600E mutation was serial diluted with DNA from a wt $B R A F$ cell line $\mathrm{K}-562$, to generate a sensitivity panel consisting of 0 , $0.1 \%, 0.25 \%, 0.5 \%, 1 \%, 2.5 \%, 5 \%, 10 \%, 20 \%$ and $50 \%$ of BRAF V600E allele in a wild-type background. The PCR was performed under the optimized condition as above.

\section{Results}

\section{Method establishment}

The BRAF V600E ARMS-PCR assay contains 4 primers in a single PCR reaction tube with the two outside primers designed to amplify a common fragment of $200 \mathrm{bp}$ flanking the mutation site which can serve as an internal amplification control (Figure 1A). The two internal primers are either specific for the mutant sequence or the wild-type sequence. The mutant and wild-type sequences are distinguishable by the difference of fragment size, as the amplified wild-type fragment is $97 \mathrm{bp}$, while the mutant fragment is $144 \mathrm{bp}$. The concentrations of PCR primers and magnesium, the annealing temperature and other cycling parameters were determined by multiple exploring studies, and the condition given here is the final optimized one.

\section{Assay sensitivity}

To assess the analytical sensitivity of the assay, $B R A F$ V600E mutation containing DNA was spiked into wildtype BRAF DNA, the PCR was performed and showed that the assay we used could detect as low as, if not better than, 0.5\% BRAF V600E allele in the background of wild-type DNA (Figure 1B). Therefore, the analytical sensitivity of the assay is $0.5 \%$. 


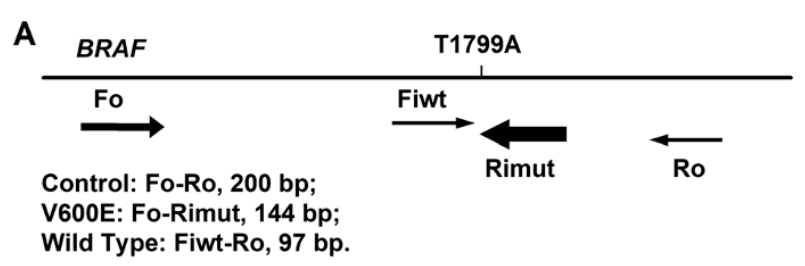

B

BRAF V600E (\%)

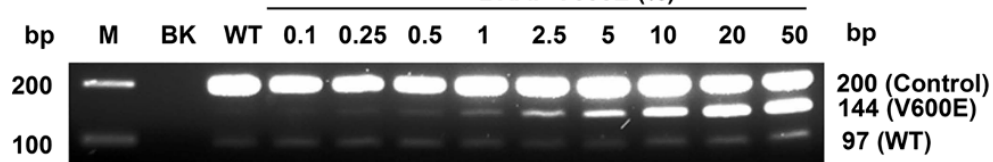

Figure 1 BRAF V600E ARMS-PCR. A, Four PCR primers are included in one PCR tube. Fo-Ro primer pair generates a common fragment of $200 \mathrm{bp}$ flanking the mutation site. Fo-Rimut primer pair generates the $144 \mathrm{bp}$ fragment specific to BRAF V600E. Fiwt-Ro primer pair generates a 97 bp fragment specific to wild-type BRAF. B, Sensitivity study. Agarose gel electrophoresis showed band pattern of a mixing study using BRAF V600E positive HT-29 cell DNA spiked into K-562 cell DNA at wide range of ratio namely $0,0.1 \%, 0.25 \%, 0.5 \%, 1 \%, 2.5 \%, 5 \%, 10 \%, 20 \%$ and $50 \%$. The assay can detect 0.5\% BRAF V600E allele in a wild-type background. M, 100 bp DNA marker; BK, blank (no DNA) control.

Assay validation and comparison with direct dideoxy sequencing using thyroid tumor specimens

We then analyzed BRAF V600E in thyroid tumors using the ARMS-PCR method. A total of 72 thyroid tumors were tested, including 55 PTCs and 17 follicular tumors. Among 55 PTCs, 33 were conventional type, 12 were tall-cell variant, and 10 were follicular variant (Table 1 ). ARMS-PCR results showed that 22 out of $33(67 \%)$ of the conventional PTC, 8 out of $12(75 \%)$ of the tall-cell variant of PTC, and none of the 10 follicular variant of PTC harbored BRAF V600E mutation. Interestingly, none of the 14 follicular adenomas and 3 follicular carcinomas showed BRAF V600E mutation.

As a comparison, automated dideoxy sequencing was used to analyze 42 tumors including all $30 B R A F$ V600E positive tumors and 12 of the $B R A F$ V600E negative tumors from ARMS-PCR assayed samples. Among the 30 BRAF V600E positive tumors detected with ARMSPCR assay, direct sequencing identified the mutation in 27 tumors, but failed to identify 3 tumors that had $B R A F$ V600E mutation, possibly due to the lower sensitivity of detection of automated dideoxy sequencing. Figure 2A depicts the representative ARMS-PCR results, showing samples 9, 26 and 32 with faint, but clearly visible $B R A F$

Table 1 BRAF V600E mutation rate in thyroid tumors

\begin{tabular}{clll}
\hline Tumor & $\begin{array}{l}\text { Sample } \\
\text { number }\end{array}$ & Positive & $\begin{array}{l}\text { Positive } \\
\text { rate (\%) }\end{array}$ \\
\hline Papillary Thyroid Carcinoma & $\mathbf{5 5}$ & $\mathbf{3 0}$ & $\mathbf{5 5}$ \\
Conventional Type & 33 & 22 & 67 \\
Tall-cell Variant & 12 & 8 & 75 \\
Follicular Variant & 10 & 0 & 0 \\
Follicular Tumor & $\mathbf{1 7}$ & $\mathbf{0}$ & $\mathbf{0}$ \\
Follicular Adenoma & 14 & 0 & 0 \\
Follicular Carcinoma & 3 & 0 & 0 \\
\hline
\end{tabular}

V600E bands (144 bp). This is comparable to the mutant band intensity of the $2.5 \% \mathrm{~V} 600 \mathrm{E}$ allele burden positive control included in the study. Figure $2 \mathrm{~B}$ depicts the representative sequencing result for sample 9, showing the mutant signal was below the detection limit of the assay. While ARMS-PCR for sample 13 showed a strong V600E mutant band, and direct sequencing showed A/T double peaks with approximately equal height (Figure 2C). Histologic study of specimen 9 showed that the tumor constituted only a small fraction of the tissue area and sample 13 had a high tumor percentage (Figure 2D). These two cases illustrate the importance of high assay sensitivity of our ARMS-PCR assay to detect low BRAF V600E allele burdens in tumor samples. The assay results for the 12 BRAF V600E negative tumors were concordant between the ARMS-PCR and direct sequencing. All 14 cases of follicular adenomas had no mutated band detected by ARMS-PCR, showing the specificity of our assay was $100 \%$ in this validation study.

Overall, our results indicate that ARMS-PCR is more sensitive than automated dideoxy sequencing in detecting low BRAF V600E allele burdens in FFPE tumor specimen.

\section{Discussion}

For the development and implementation of personalized medicine, a sensitive, specific, low-cost and easyto-implement assay to identify various genetic alterations such as BRAF V600E mutation is needed. By selecting primer pair and optimizing PCR cycling conditions, we achieved this goal by using ARMS based PCR. One of the advantages of ARMS-PCR is that the assay is designed to amplify a relative larger common fragment of DNA that flanks the mutation site in all samples regardless of their mutation status. This common fragment conveniently serves as an internal control for 


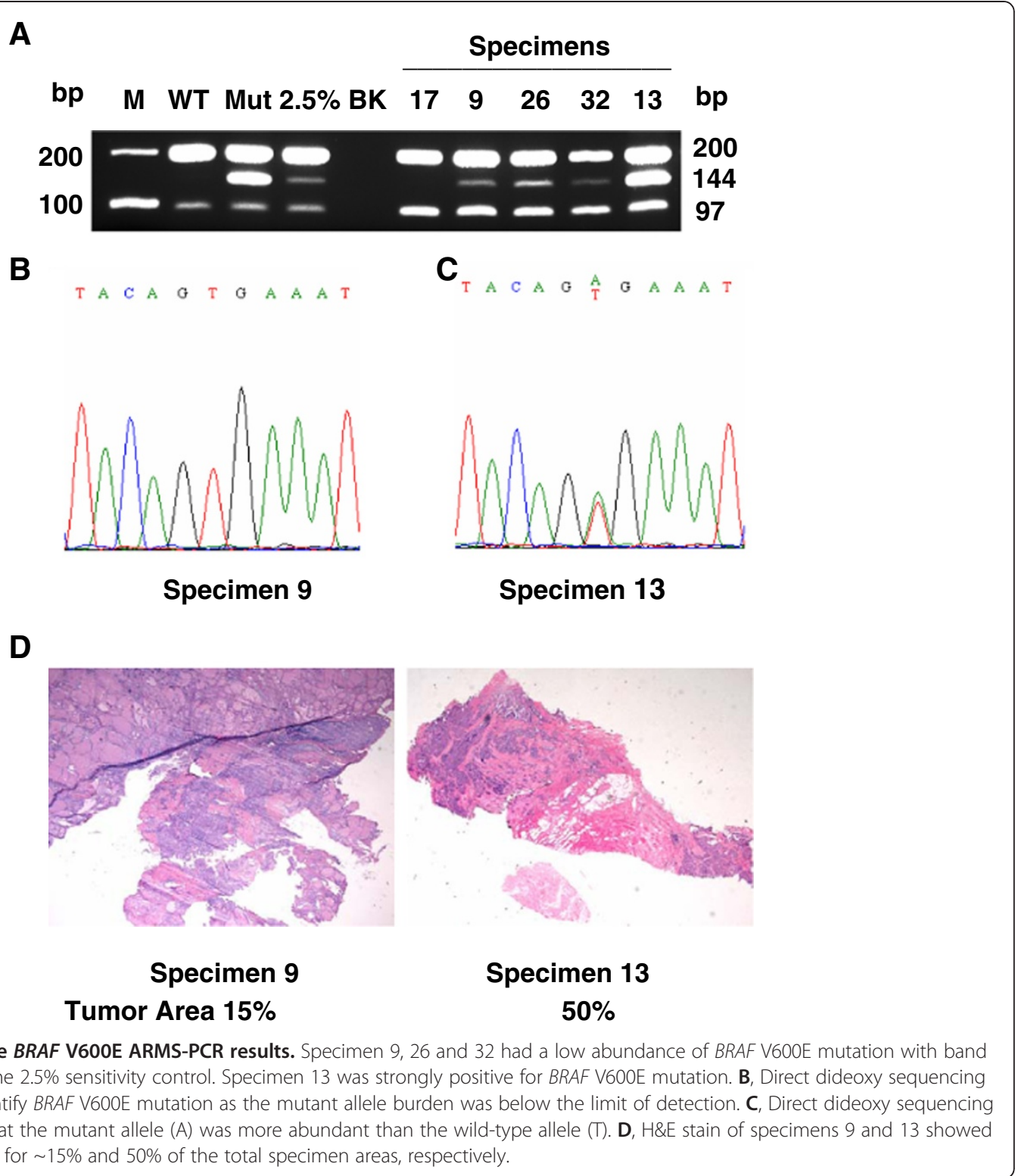

template DNA quality as well as potential PCR inhibition. The mutant or wild-type specific PCR amplifications take place in the same reaction tube, thereby allowing the mutant or wild-type specific PCR primers to compete for binding to very limited templates. To increase the sensitivity for detecting this mutation, we tried to change the ratio of four primers and found that the combination of $400 \mathrm{nM}$ primer Fo, $200 \mathrm{nM}$ primer Ro and Fiwt, 800 nM primer Rimut resulted the strongest mutant band. The primer binding to template varies based on their annealing conditions, but relative high Fo and the highest Rimut primer concentrations might favor the production of mutant product in our design. In addition, relative low concentration for Fiwt and Ro primers might reduce full length and wild type product formation by the competition effect of each primer. By such a design, the three products were produced at reasonably comparable levels. Otherwise, the wild type or whole length bands might overshadow the weak mutant band if the mutant BRAF V600E abundance is low, which is frequently the case for clinical specimens. With this study, we improved assay sensitivity to as low as $0.5 \%$ mutant allele level in the background of wild-type DNA, which is quite sensitive among ARMS-PCR methods [21]. This sensitivity is very difficult to reach with direct dideoxy sequencing which has the sensitivity of $15-20 \%$, and with pyrosequencing which has greatly increased sensitivity to about $2 \%$ [22,23]. Considering DNA samples obtained from FFPE tissue is often fragmented due to damage by formalin fixation, we designed 
our PCR product size to be small (no more than $200 \mathrm{bp}$ ) to maximize the chance of successful amplification. This was proven to be helpful since all 72 FFPE samples had successful amplification.

The reported prevalence of BRAF V600E mutation for conventional PTC varied from $36 \%$ to $67 \%$ in the US and European studies [7,8,24-27], and was $83 \%$ in a Korean study [28]. The difference in prevalence could be due to different study population or different methodologies used. The prevalence of BRAF V600E mutation in the tallcell variant PTC is in general higher than that of the conventional type, with a mean prevalence of $77 \%$ in several studies [8]. On the contrary, the follicular variant of PTC is rarely involved by $B R A F \mathrm{~V} 600 \mathrm{E}$ mutation, with a mean prevalence of $12 \%$ [8]. Using ARMS-PCR, we tested 72 thyroid tumors and determined that the frequencies of $B R A F$ V600E mutation in the conventional, tall-cell and follicular variants of PTC were $66 \%, 75 \%$ and $0 \%$, respectively. Our frequency of BRAF V600E mutation in conventional PTC was at the high end of the reported results, possibly reflecting our improved assay sensitivity compared with automated DNA sequencing, which was the method used in many of the reported studies. Our study showed that DNA sequencing method missed 3 out of 30 PTC samples with BRAF V600E detected by ARMS-PCR, resulting in a false negative rate of $10 \%$. In our validation study, the assay specificity is $100 \%(14 / 14)$ based on negative mutation in follicular adenoma. This is consistent with previous reports since benign follicular adenoma has not been found to harbor the BRAF mutation [8].

BRAF V600E mutation testing has demonstrated utility in helping select CRC patients who are considering monoclonal antibody therapy as wild-type $B R A F$ is required for response to anti-EGFR antibodies [9] and improve diagnostic accuracy in thyroid FNA samples $[12,13]$. In addition, BRAF V600E mutation is associated with sporadic microsatellite instable CRC, but not hereditary non-polyposis colorectal cancer (HNPCC) syndrome [29,30]. Therefore, the presence of BRAF V600E mutation is an exclusion criteria for HNPCC genetic testing [29,30]. BRAF V600E mutation testing can also help facilitate clinical studies of BRAF-targeted therapies [31]. The improved understanding of the role BRAF mutations in cancer diagnosis, prognosis and treatment has increased the need for $B R A F$ mutation testing $[4,32]$.

New methods are constantly being developed for BRAF V600E mutation detection. Shifted termination assay (STA) developed by TrimGen Corporation declared the sensitivity of 1-5\% [33]. Lang et al. developed an allele-specific, also known as ARMS, real-time PCR using Taqman probe to increase the sensitivity to $1 \%$ and using internal control to exclude false negative results [34]. Morandi et al. developed an allele specific locked nucleic acid (LNA) quantitative PCR assay using
LNA-modified allele specific primers and LNA-modified beacon probes to achieve sensitivity of $0.1 \%$ [35]. Dualpriming oligonucleotide (DPO)-based multiplex PCR was commercially available from Seegene (Seoul, Korea) and has a sensitivity of 2\% [36]. Qiagen developed a $B R A F$ mutation detection PCR kit with a sensitivity of $1.27 \%$. Our method using ARMS-PCR therefore appears to have high sensitivity $(0.5 \%)$ for $B R A F$ V600E mutation detection.

\section{Conclusions}

We have developed a sensitive, specific and low-cost ARMS-PCR assay to detect BRAF V600E mutation. Comparative study showed that this assay is superior to automated dideoxy sequencing in terms of assay sensitivity, turn-around time and costs. The ARMS-PCR assay can be easily implemented by many molecular laboratories for BRAF V600E mutation testing. Our method provides one of the most sensitive methods for $B R A F$ V600E gene mutation detection. The principal of our study design can be potentially adapted to detect other low abundance point mutations such as tumors with rich background stroma and post-treatment tumor samples.

\section{Competing interests}

The authors declare that they have no competing interests.

\section{Authors' contributions}

$\mathrm{TH}$ : design, data analysis, paper writing submission. JZ: design experiments and implement. WWZ: design study, sample collection, data analysis and paper writing. All authors read and approved the final manuscript.

\section{Acknowledgments}

We thank Dr. Minghao Zhong for critical reading of the manuscript.

Received: 26 September 2012 Accepted: 9 October 2012

Published: 16 January 2013

\section{References}

1. Ciardiello F, Tortora G: EGFR antagonists in cancer treatment. N Engl J Med 2008, 358:1160-1174.

2. Zhang BH, Guan KL: Activation of B-Raf kinase requires phosphorylation of the conserved residues Thr598 and Ser601. EMBO J 2000, 19:5429-5439.

3. Turjanski AG, Vaque JP, Gutkind JS: MAP kinases and the control of nuclear events. Oncogene 2007, 26:3240-3253.

4. Pratilas CA, Solit DB: Therapeutic strategies for targeting BRAF in human cancer. Rev Recent Clin Trials 2007, 2:121-134.

5. Tiacci E, Trifonov V, Schiavoni G, Holmes A, Kern W, Martelli MP, Pucciarini A, Bigerna B, Pacini R, Wells VA, et al: BRAF mutations in hairy-cell leukemia. N Engl J Med 2011, 364:2305-2315.

6. Davies H, Bignell GR, Cox C, Stephens P, Edkins S, Clegg S, Teague J, Woffendin H, Garnett MJ, Bottomley W, et al: Mutations of the BRAF gene in human cancer. Nature 2002, 417:949-954.

7. Nikiforova MN, Kimura ET, Gandhi M, Biddinger PW, Knauf JA, Basolo F, Zhu Z, Giannini R, Salvatore G, Fusco A, et al: BRAF mutations in thyroid tumors are restricted to papillary carcinomas and anaplastic or poorly differentiated carcinomas arising from papillary carcinomas. J Clin Endocrinol Metab 2003, 88:5399-5404.

8. Xing M: BRAF mutation in thyroid cancer. Endocr Relat Cancer 2005, 12:245-262.

9. Di Nicolantonio F, Martini M, Molinari F, Sartore-Bianchi A, Arena S, Saletti P, De Dosso S, Mazzucchelli L, Frattini M, Siena S, Bardelli A: Wild-type BRAF is 
required for response to panitumumab or cetuximab in metastatic colorectal cancer. J Clin Oncol 2008, 26:5705-5712.

10. Siena S, Sartore-Bianchi A, Di Nicolantonio F, Balfour J, Bardelli A: Biomarkers predicting clinical outcome of epidermal growth factor receptor-targeted therapy in metastatic colorectal cancer. J Nat/ Cancer Inst 2009, 101:1308-1324

11. Normanno N, Tejpar S, Morgillo F, De Luca A, Van Cutsem E, Ciardiello F: Implications for KRAS status and EGFR-targeted therapies in metastatic CRC. Nature reviews 2009, 6:519-527.

12. Salvatore G, Giannini R, Faviana P, Caleo A, Migliaccio I, Fagin JA, Nikiforov YE, Troncone G, Palombini L, Basolo F, Santoro M: Analysis of BRAF point mutation and RET/PTC rearrangement refines the fine-needle aspiration diagnosis of papillary thyroid carcinoma. J Clin Endocrinol Metab 2004, 89:5175-5180

13. Cohen $Y$, Rosenbaum E, Clark DP, Zeiger MA, Umbricht CB, Tufano RP, Sidransky D, Westra WH: Mutational analysis of BRAF in fine needle aspiration biopsies of the thyroid: a potential application for the preoperative assessment of thyroid nodules. Clin Cancer Res 2004, 10:2761-2765

14. Jin L, Sebo TJ, Nakamura N, Qian X, Oliveira A, Majerus JA, Johnson MR, Lloyd RV: BRAF mutation analysis in fine needle aspiration (FNA) cytology of the thyroid. Diagn Mol Pathol 2006, 15:136-143.

15. Pichler M, Balic M, Stadelmeyer E, Ausch C, Wild M, Guelly C, Bauernhofer T, Samonigg $\mathrm{H}$, Hoefler $\mathrm{G}$, Dandachi N: Evaluation of high-resolution melting analysis as a diagnostic tool to detect the BRAF V600E mutation in colorectal tumors. J Mol Diagn 2009, 11:140-147.

16. Jarry A, Masson D, Cassagnau E, Parois S, Laboisse C, Denis MG: Real-time allele-specific amplification for sensitive detection of the BRAF mutation V600E. Mol Cell Probes 2004, 18:349-352.

17. Pinzani P, Santucci C, Mancini I, Simi L, Salvianti F, Pratesi N, Massi D, De Giorgi V, Pazzagli M, Orlando C: BRAFV600E detection in melanoma is highly improved by COLD-PCR. Clin Chim Acta 2011, 412:901-905.

18. Monzon FA, Ogino S, Hammond ME, Halling KC, Bloom KJ, Nikiforova MN: The role of KRAS mutation testing in the management of patients with metastatic colorectal cancer. Arch Pathol Lab Med 2009, 133:1600-1606.

19. Chen Q, Lu P, Jones AV, Cross NC, Silver RT, Wang YL: Amplification refractory mutation system, a highly sensitive and simple polymerase chain reaction assay, for the detection of JAK2 V617F mutation in chronic myeloproliferative disorders. J Mol Diagn 2007, 9:272-276.

20. Melanie JP, Mary Frances M: The V617F JAK2 mutation and the myeloproliferative disorders. Hematol Oncol 2005, 23:91-93.

21. Ellison G, Donald E, McWalter G, Knight L, Fletcher L, Sherwood J, Cantarini M, Orr M, Speake G: A comparison of ARMS and DNA sequencing for mutation analysis in clinical biopsy samples. J Exp Clin Cancer Res 2010, 29:132.

22. Tan YH, Liu Y, Eu KW, Ang PW, Li WQ, Salto-Tellez M, lacopetta B, Soong R: Detection of BRAF V600E mutation by pyrosequencing. Pathology 2008, 40:295-298.

23. Lee ST, Kim SW, Ki CS, Jang JH, Shin JH, Oh YL, Kim JW, Chung JH: Clinical implication of highly sensitive detection of the BRAF V600E mutation in fine-needle aspirations of thyroid nodules: a comparative analysis of three molecular assays in 4585 consecutive cases in a BRAF V600E mutation-prevalent area. J Clin Endocrinol Metab 2012, 97:2299-2306.

24. Kimura ET, Nikiforova MN, Zhu Z, Knauf JA, Nikiforov YE, Fagin JA: High prevalence of BRAF mutations in thyroid cancer: genetic evidence for constitutive activation of the RET/PTC-RAS-BRAF signaling pathway in papillary thyroid carcinoma. Cancer Res 2003, 63:1454-1457.

25. Xu X, Quiros RM, Gattuso P, Ain KB, Prinz RA: High prevalence of BRAF gene mutation in papillary thyroid carcinomas and thyroid tumor cell lines. Cancer Res 2003, 63:4561-4567.

26. Cohen Y, Xing M, Mambo E, Guo Z, Wu G, Trink B, Beller U, Westra WH, Ladenson PW, Sidransky D: BRAF mutation in papillary thyroid carcinoma. J Natl Cancer Inst 2003, 95:625-627.

27. Trovisco V, de Castro Vieira I, Soares P, Maximo V, Silva P, Magalhaes J, Abrosimov A, Guiu XM, Sobrinho-Simoes M: BRAF mutations are associated with some histological types of papillary thyroid carcinoma. J Pathol 2004, 202:247-251.

28. Kim KH, Kang DW, Kim SH, Seong IO, Kang DY: Mutations of the BRAF gene in papillary thyroid carcinoma in a Korean population. Yonsei Med J 2004, 45:818-821.
29. Domingo E, Laiho P, Ollikainen M, Pinto M, Wang L, French AJ, Westra J, Frebourg $T$, Espin $E$, Armengol $M$, et al: BRAF screening as a low-cost effective strategy for simplifying HNPCC genetic testing. J Med Genet 2004, 41:664-668.

30. Domingo E, Niessen RC, Oliveira C, Alhopuro P, Moutinho C, Espin E, Armengol M, Sijmons RH, Kleibeuker JH, Seruca R, et al: BRAF-V600E is not involved in the colorectal tumorigenesis of HNPCC in patients with functional MLH1 and MSH2 genes. Oncogene 2005, 24:3995-3998.

31. Tsai J, Lee JT, Wang W, Zhang J, Cho H, Mamo S, Bremer R, Gillette S, Kong J. Haass NK, et al: Discovery of a selective inhibitor of oncogenic B-Raf kinase with potent antimelanoma activity. Proc Natl Acad Sci U S A 2008, 105:3041-3046.

32. Nikiforova MN, Nikiforov YE: Molecular genetics of thyroid cancer: implications for diagnosis, treatment and prognosis. Expert Rev Mol Diagn 2008, 8:83-95.

33. Benoit NE, Goldenberg D, Deng SX, Rosenbaum E, Cohen Y, Califano JA, Shackelford WH, Wang XB, Sidransky D: Colorimetric approach to highthroughput mutation analysis. Biotechniques 2005, 38:635-639.

34. Lang AH, Drexel H, Geller-Rhomberg S, Stark N, Winder T, Geiger K, Muendlein A: Optimized allele-specific real-time PCR assays for the detection of common mutations in KRAS and BRAF. J Mol Diagn 2011, 13:23-28.

35. Morandi L, de Biase D, Visani M, Cesari V, De Maglio G, Pizzolitto S, Pession A, Tallini G: Allele Specific Locked Nucleic Acid Quantitative PCR (ASLNAqPCR): an accurate and cost-effective assay to diagnose and quantify KRAS and BRAF mutation. PLoS One 2012, 7:e36084.

36. Lee ST, Kim SW, Ki CS, Jang JH, Shin JH, Oh YL, Kim JW, Chung JH: Clinical implication of highly sensitive detection of the BRAF V600E mutation in fine-needle aspirations of thyroid nodules: a comparative analysis of three molecular assays in 4585 consecutive cases in a BRAF V600E mutation-prevalent area. J Clin Endocrinol Metab 2012, 97:2299-2306.

doi:10.1186/2050-7771-1-3

Cite this article as: Huang et al:: Sensitive detection of BRAF V600E mutation by Amplification Refractory Mutation System (ARMS)-PCR. Biomarker Research 2013 1:3

\section{Submit your next manuscript to BioMed Central and take full advantage of:}

- Convenient online submission

- Thorough peer review

- No space constraints or color figure charges

- Immediate publication on acceptance

- Inclusion in PubMed, CAS, Scopus and Google Scholar

- Research which is freely available for redistribution 